ARTICLE

\title{
Evaluation of antimycobacterial activity from marine and freshwater microalgae
}

Evaluación de la actividad antimicobacteriana de microalgas dulceacuícolas y marinas

\author{
Duahmet A. Ruiz-Güereca ${ }^{1,3}$, Alexei F. Licea-Navarro ${ }^{2}$ and M. del Pilar Sánchez-Saavedra ${ }^{3 *}$ \\ ${ }^{1}$ Departamento de Microbiología, Centro de Investigación Científica y de Educación Superior de Ensenada, Baja California, México \\ ${ }^{2}$ Departamento de Innovación Biomédica, Centro de Investigación Científica y de Educación Superior de Ensenada, Baja California, \\ México \\ ${ }^{3}$ Departamento de Acuicultura, Centro de Investigación Científica y de Educación Superior de Ensenada, Carretera Tijuana-Ensenada \\ \#3918, Fraccionamiento Zona Playitas, Zip code 22860, Ensenada, Baja California, México \\ *Corresponding author: psanchez@cicese.mx
}

\begin{abstract}
Resumen.- La tuberculosis es considerada una de las enfermedades epidemiológicas más importantes a nivel mundial. El tratamiento actual para la tuberculosis consiste en la combinación y uso de fármacos antituberculoso por al menos 9 meses. En la actualidad, la búsqueda de nuevos agentes farmacológicos para el tratamiento de la tuberculosis es una tarea urgente. Las microalgas producen una amplia variedad de moléculas que poseen actividades biológicas de interés farmacéutico. Por lo tanto, el objetivo de este trabajo fue evaluar la actividad antimicobacteriana de los extractos crudos hexánicos obtenidos de 6 microalgas: Chlamydomonas mexicana, Porphyridium cruentum, Isochrysis galbana, Rhodomonas sp., Aphanocapsa marina y Nitzschia palea. Todos los extractos crudos inhibieron al menos el 90\% del crecimiento de Mycobacterium tuberculosis H37Rv a una concentración de $100 \mu \mathrm{g} \mathrm{ml}{ }^{-1}$. El extracto crudo obtenido de I. galbana presentó la mayor actividad antimicobacteriana con un porcentaje de inhibición igual al del fármaco antituberculoso isoniazida y con una concentración inhibitoria mínima de $50 \mu \mathrm{g} \mathrm{ml}^{-1}$. Estos hallazgos demuestran que las microalgas son una excelente fuente para la búsqueda de nuevos compuestos antimicobacterianos.
\end{abstract}

Palabras clave: Tuberculosis, microalgas, extracto crudo, ensayo en microplaca con sal de tetrazolio, actividad antimicobacteriana

\begin{abstract}
Tuberculosis is considered one of the most important epidemiological diseases worldwide. The current treatment for tuberculosis is a combination of antituberculosis drugs for at least 9 months. Nowadays, the search for new pharmacological agents for the treatment of tuberculosis is an urgent endeavor. Microalgae produce a wide variety of molecules that possess biological activities of pharmaceutical interest. Therefore, the objective of this work was to evaluate the antimycobacterial activity of hexane crude extracts of 6 microalgae: Chlamydomonas mexicana, Porphyridium cruentum, Isochrysis galbana, Rhodomonas sp., Aphanocapsa marina, and Nitzschia palea. All of the hexane extracts inhibited at least $90 \%$ of the growth of Mycobacterium tuberculosis $\mathrm{H} 37 \mathrm{Rv}$ at a concentration of $100 \mu \mathrm{g} \mathrm{ml}^{-1}$. The hexane crude extract of $I$. galbana had the highest antimycobacterial activity displaying a percentage inhibition that

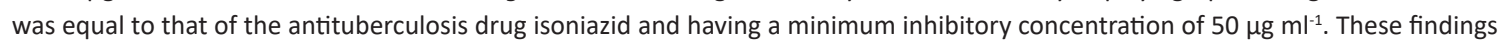
demonstrate that microalgae are an excellent source for the search of novel antimycobacterial compounds.
\end{abstract}

Key words: Tuberculosis, microalgae, crude extract, tetrazolium microplate assay, antimycobacterial activity

\section{INTRODUCTION}

Tuberculosis (TB), acquired immune deficiency syndrome (HIV/AIDS), and malaria are considered the most important epidemiological diseases worldwide (Sotgiu \& Migliori 2014). TB is a systemic, chronic disease that primarily affects the respiratory system; the main causative agent of TB in humans is Mycobacterium tuberculosis (Mtb). In 2015, it was estimated that one-third of the world's population was infected with Mtb and that $10 \%$ of these subjects could develop TB (WHO 2016). In Mexico, approximately 15,000 new cases of TB and 2,000 deaths due to this disease are registered annually (INDRE 2014). The morbidity rate varies among states of Mexico, the highest of which occurs in the state of Baja California, with 42 cases of TB per 100,000 habitants per year (INDRE 2014). The current treatment of TB is a combination of antituberculosis drugs over 9 to 12 months to ensure the total eradication of mycobacteria (World Health Organization 2016). This extended period of medication is one of the main factors of nonadherence, which favors the appearance of drug-resistant Mtb strains (Migliori et al. 2007). Certain infectious diseases that are caused by drug-resistant bacteria can be treated with alternative drugs (Powers 2004). However, this approach cannot be applied to TB, because the drugs that are used 
to treat drug-resistant Mtb strains are more expensive, less effective, and more toxic (Sotgiu \& Migliori 2014). Due to the need for more efficacious antituberculosis drugs, namely those with a shorter treatment duration, few side effects and that do not require being combined with other drugs and an increase in drug-resistant Mtb strains, the search for new pharmacological agents for the treatment of TB is a critical issue worldwide (Hoagland et al. 2016).

Microalgae, s. ampl. considering cyanobacteria as microalgae, are cosmopolitan microorganisms, because they are found in various aquatic and terrestrial habitats, even in extreme environments, such as hypersaline waters, frozen lakes, and hydrothermal vents (Whitton \& Potts 2000). To survive in such inhospitable environments, microalgae produce a wide variety of compounds. These compounds have demonstrated to display a range of bioactivities, such as antiviral, anticancer, antifungal, and antibacterial, which has fascinated researchers, based on their incredible pharmaceutical potential (Pulz \& Gross 2004).

Different microalgae strains (46) were studied to evaluate their potential antimicrobial and antimycobacterial activities related to strain diversity. Results showed that extracts of two diatoms, Skeletonema costatum and Chaetoceros pseudocurvisetus have anti-tuberculosis activity and were only active when cultured in the control and phosphate starvation conditions. The organic and water extracts were also tested, and we found that only the organic extracts of both diatoms were active. The chemical characterizations of the compounds are related to chlorophyll breakdown and lipids (Lauritano et al. 2018).

Antimycobacterial activity has been found in methanolic extracts of cyanobacteria for the genus Oscillatoria, Spirulina, Anabaena, Scytonema and Hapalisiphon (Rao et al. 2007). A potent antimycobacterial effect of anthraquinone derivatives has also been reported from Eucapsia sp. (Sturdy et al. 2010). Two new compounds (carbamidocyclofanes) have been discovered for the cyanobacteria Nostoc sp. with antimycobacterium activity (Luo et al. 2014). The hexanic extracts from the cyanobacteria Mycrocystis aeruginosa inhibit the growth of Mycobacterium tuberculosis, $M$. terrae, M. chelonae and M. kansasii. This cytotoxic effect is related to their microcystins content (monocyclic heptapeptides toxins that act as inhibitors or serine/threonine protein phosphatases) (Dawson 1998, Fernandes-Ramos et al. 2015). Our research group, has satisfactorily screened diverse groups of microalgae for antibacterial activity (Sánchez-Saavedra et al. 2010, González-Davis et al. 2012, Molina-Cárdenas \& Sánchez-Saavedra 2017). Thus, this work was focused on the evaluation of the antimycobacterial activity of hexanic crude extracts obtained from six different phyla of microalgae.

\section{MATERials AND Methods}

\section{Microalgal Material}

Microalgal strains examined in this work (Table 1) were Chlamydomonas mexicana (NIES-2218), Porphyridium cruentum (NIES-2138), Isochrysis galbana (CCMP 1323), and Rhodomonas sp. (NIES-1005). Additionally, the cyanobacteria Aphanocapsa marina and the diatom Nitzschia palea, isolated earlier by our group (FierroReséndiz 2006, Jiménez-Valera \& Sánchez-Saavedra 2016) were also examined. These microalgal strains were grown in monospecific, nonaxenic batch cultures in Fernbach flasks that contained 2 L of "f" medium (Guillard \& Ryther 1962). The microalgal cultures were kept at $20^{\circ} \mathrm{C}$ under continuous light that was provided by cold white light lamps

Table 1. List of microalgae strains, the type of environment and, the strain bank or place of isolation from which they were obtained / Lista de las microalgas utilizadas, el tipo de ambiente y el lugar de aislamiento o en su caso el cepario del que provienen

\begin{tabular}{|c|c|c|}
\hline Microalgae strain & Environment & Strain bank or place of isolation \\
\hline \multicolumn{3}{|l|}{ Cyanophyta } \\
\hline Aphanocapsa marina & Marine & Ensenada, Baja California, México \\
\hline \multicolumn{3}{|l|}{ Chlorophyta } \\
\hline Chlamydomonas mexicana & Freshwater & National Institute for Environmental Studies (NIES) \\
\hline \multicolumn{3}{|l|}{ Bacillariophyta } \\
\hline Nitzschia palea & Freshwater & Mexicali, Baja California, México \\
\hline \multicolumn{3}{|l|}{ Criptophyta } \\
\hline Rhodomonas sp. & Marine & National Institute for Environmental Studies (NIES) \\
\hline \multicolumn{3}{|l|}{ Haptophyta } \\
\hline Isochrysis galbana & Marine & National Center for Marine Algae and Microbiota (BIGELOW) \\
\hline \multicolumn{3}{|l|}{ Rhodophyta } \\
\hline Porphyridium cruentum & Marine & National Institute for Environmental Studies (NIES) \\
\hline
\end{tabular}


(F40D-EX, General Electric ${ }^{\circledR}$ ) at $100 \mu \mathrm{mol}$ photons $\mathrm{m}^{-2} \mathrm{~s}^{-1}$. Growth curves of each microalgal strain were generated to identify their stationary growth phase. To this end, $1 \mathrm{ml}$ of culture sample was taken daily, and its optical density (OD) was measured at $680 \mathrm{~nm}$ on a spectrophotometer $\left(6000\right.$ UV-VIS, Hach $\left.^{\circledR}\right)$. The stationary growth phase was defined as the stage in which the OD did not change considerably over 4 consecutive days. The OD values were transformed to a logarithmic scale and plotted. Then, microalgae biomass was harvested during the stationary growth phase by centrifuging the cultures at 3,500 $\mathrm{g}$ and $5{ }^{\circ} \mathrm{C}$ for $15 \mathrm{~min}$. Then, the supernatant was discarded, the cell pellet was lyophilized. After the lyophilization process, samples were weighed out in order to obtain the yield of the biomass produced from each microalgal strain. Lastly, the lyophilized biomass was stored at $-20^{\circ} \mathrm{C}$.

\section{Preparation of microalgal Crude extracts}

Lipophilic extracts of the lyophilized biomass were obtained from each microalgal strain using hexane (ACS grade, Fermont $^{\circledR}$ ). Briefly, $50 \mathrm{mg}$ of lyophilized biomass was rehydrated with $500 \mu \mathrm{l}$ of sterile distilled water, frozen in liquid nitrogen, and thawed at room temperature; this process was performed 3 times to lyse the cells in the lyophilized biomass. The biomass was then transferred to amber flasks, to which $50 \mathrm{ml}$ hexane was then added. The biomass-solvent mixture was allowed to stir in darkness at $150 \mathrm{rpm}$ and $21^{\circ} \mathrm{C}$ overnight on an orbital shaker. Next, the sample was filtered, and the filtrate (i.e., the hexane extract, was recovered). Subsequently, the resulting extracts were dried at $30{ }^{\circ} \mathrm{C}$ in vacuo to evaporate the hexane and avoid their toxic effect. The dried extracts were weighed out to measure the extract yield. After that, crude extracts were dissolved in 100\% dimethylsulfoxide (DMSO) (ACS grade, Fermont ${ }^{\circledR}$ ) to a concentration of $10 \mathrm{mg} \mathrm{ml}^{-1}$ (Chlipala et al. 2009). Finally, the crude extracts were stored in glass amber vials at -20 ${ }^{\circ} \mathrm{C}$ until their use in the antimycobacterial activity assays. All the extraction procedures were performed considering the recommendations mentioned on the implementation of antimicrobial screens (Beutler 2009, Fallarero et al. 2015).

\section{MYCOBACTERIAL GROWTH CONDITIONS AND INOCULUM PREPARATION}

The Mtb strain that we used was H37Rv (ATCC 27294 ${ }^{\circledR}$ ), which is sensitive to the 5 first-line antituberculosis drugs. The mycobacteria were cultured in 10-ml test tubes with Lowenstein-Jensen medium (MacFaddin 1985) and maintained for 3 weeks at $37^{\circ} \mathrm{C}$ in an incubator. At the end of the incubation, the Mtb cultures were in the exponential growth phase and thus ready for use in the antimycobacterial activity assays. The Mtb inoculum was prepared by taking loops of the mycobacteria that was cultured in LowensteinJensen medium and transferring them into a tube with $10 \mathrm{ml}$ sterile distilled water. Then, the Mtb clusters were disrupted and homogenized using a vortex to produce a mycobacterial suspension.

Subsequently, a volume of the mycobacterial suspension was transferred to a new tube with $10 \mathrm{ml}$ sterile distilled water until reaching a turbidity that was similar to that of tube \#1 of the McFarland scale, that is equivalent to $3 \times 10^{8}$ CFU ml-1. Finally, $0.5 \mathrm{ml}$ of this suspension was added to $9.5 \mathrm{ml}$ of Middlebrook 7H9 medium (Becton, Dickinson and Company ${ }^{\circledR}$ ) that was supplemented with $0.5 \%$ glycerol (Sigma-Aldrich ${ }^{\circledR}$ ) and 10\% OADC (oleic acid, albumin, dextrose and catalase) (Becton, Dickinson and Company ${ }^{\circledR}$ ) resulting in a final mycobacterial concentration of $1.5 \times 10^{7}$ CFU ml-1.

\section{DETERMINATION OF THE INNOCUOUS DMSO CONCENTRATION}

The innocuous concentration of the dimethyl sulfoxide (DMSO) was determined by a colorimetric technique with microplate and different concentrations of $\operatorname{DMSO}(0.5,1,2$, 3,4 and $5 \%$ ) by triplicate (Galvao et al. 2014). The extracts were dissolving at innocuous concentration of $1 \%(10 \mathrm{mg}$ $\mathrm{ml}^{-1}$ ) with DMSO.

\section{ANTIMYCOBACTERIAL ACTIVITY ASSAYS}

The antimycobacterial activity of the extracts was measured by tetrazolium microplate assay (TEMA) (Palomino et al. 2007). Briefly, to minimize evaporation from the microplate all perimeter wells were filled with $200 \mu \mathrm{l}$ of sterile water. As a positive control, in wells B, C, and D of column 10, $50 \mu \mathrm{l}$ of the antituberculosis drug isoniazid at $4 \mu \mathrm{g} \mathrm{ml}^{-1}$ $\left(\right.$ Sigma-Aldrich ${ }^{\circledR}$ ) and $50 \mu$ of Middlebrook $7 \mathrm{H} 9$ medium supplemented with glycerol and OADC as described in the previous section were added with $100 \mu \mathrm{l}$ of mycobacterial inoculum. In wells E, F, and G of column 10, $98 \mu \mathrm{l}$ of Middlebrook 7H9 medium, $2 \mu 1$ 100\% DMSO, and 100 $\mu \mathrm{l}$ of mycobacterial inoculum were added, serving as a control for DMSO. In wells B, C, and D of column 11, 200 $\mu \mathrm{l}$ of Middlebrook $7 \mathrm{H} 9$ medium was added as the blank. As a negative control, in wells E, F, and G of column 11, $100 \mu \mathrm{l}$ of Middlebrook 7H9 medium was added with 100 $\mu \mathrm{l}$ of mycobacterial inoculum. In the remaining wells, $2 \mu \mathrm{l}$ of hexane extract was added in triplicate (i.e., the same microalgal crude extract in 3 different wells with $98 \mu \mathrm{l}$ of Middlebrook 7H9 medium). Lastly, $100 \mu \mathrm{l}$ of the mycobacterial inoculum was added, resulting in final concentrations of microalgal crude extracts and DMSO of $100 \mu \mathrm{g} \mathrm{ml}^{-1}$ and $1 \%(\mathrm{v} / \mathrm{v})$, respectively.

The microplate was kept at $37{ }^{\circ} \mathrm{C}$ for 7 days in an incubator, after which all wells received $20 \mu \mathrm{l}$ of the tetrazolium salt dye MTS (3-4,5-dimethylthiazol-2-yl-5-3carboxymethoxyphenyl-2-4-sulfophenyl-2H-tetrazolium) (Celltiter 96, Promega $\left.{ }^{\circledR}\right)$. Then, the microplate was incubated at $37^{\circ} \mathrm{C}$ for $2 \mathrm{~h}$, and the OD of the wells was 
measured at $550 \mathrm{~nm}$ on a microplate reader (Multiskan, Thermo Scientific $\left.{ }^{\circledR}\right)$. Finally, the percentage growth inhibition (\%) was determined by the following formula:

Growth inhibition $(\%)=\left[1-\left(\frac{\text { OD of test well (extract of drug) }}{\text { mean OD of negative control }}\right)\right] \times 100$

\section{DETERMINATION OF THE MINIMUM INHIBITORY CONCENTRATION (MIC)}

The MIC was determined by TEMA with the necessary modifications to calculate it. Subsequently, two-fold serial dilutions were made by taking $100 \mu$ from the wells in row $\mathrm{B}$ and transferring them to the wells sequentially from rows $\mathrm{C}$ to $\mathrm{G}$. Finally, $100 \mu \mathrm{l}$ of mycobacterial inoculum was added to all test wells resulting in concentrations for microalgal extracts from 100 to $3.1 \mu \mathrm{g} \mathrm{ml}^{-1}$ and from 1 to $0.03 \mu \mathrm{g} \mathrm{ml}^{-1}$ for isoniazid. The microplates were incubated at $37^{\circ} \mathrm{C}$ for 7 days, and the inhibition of mycobacterial growth was measured spectrophotometrically using MTS as described in the previous section. The MIC was defined as the lowest concentration of crude extract or drug that inhibited at least $90 \%$ of the mycobacterial growth (Collins \& Franzblau 1997).

\section{Statistical ANALYSiS}

One-way analysis of variance (ANOVA) was used to evaluate the differences in percentage inhibition against Mtb by the hexane crude extracts. The hypotheses underlying the one-way ANOVA were verified: the normality and the homogeneity of variance were analyzed by Shapiro-Wilks test and Brown-Forsythe test, respectively (Zar 2010). The level of significance $(\alpha)$ was 0.05 , and when significant differences arose between treatments, Fisher's least significant difference (LSD) test was used. The statistical analyses were performed using GraphPad-Prism ${ }^{\circledR}$, version 6.0 .

\section{RESULTS}

\section{Microalgal growth AND PREPARATION OF CRUDE EXTRACTS}

Four microalgal strains, A. marina, Rhodomonas sp., I. galbana, and $P$. cruentum, did not experience a conditioning phase with exponential growth from the beginning of the culture, whereas C. mexicana and N. palea did (Fig. 1). The cultures of I. galbana and Rhodomonas sp. were harvested at eleventh day of culture, while the remaining cultures were harvested on the twelfth day (Table 2). Differences
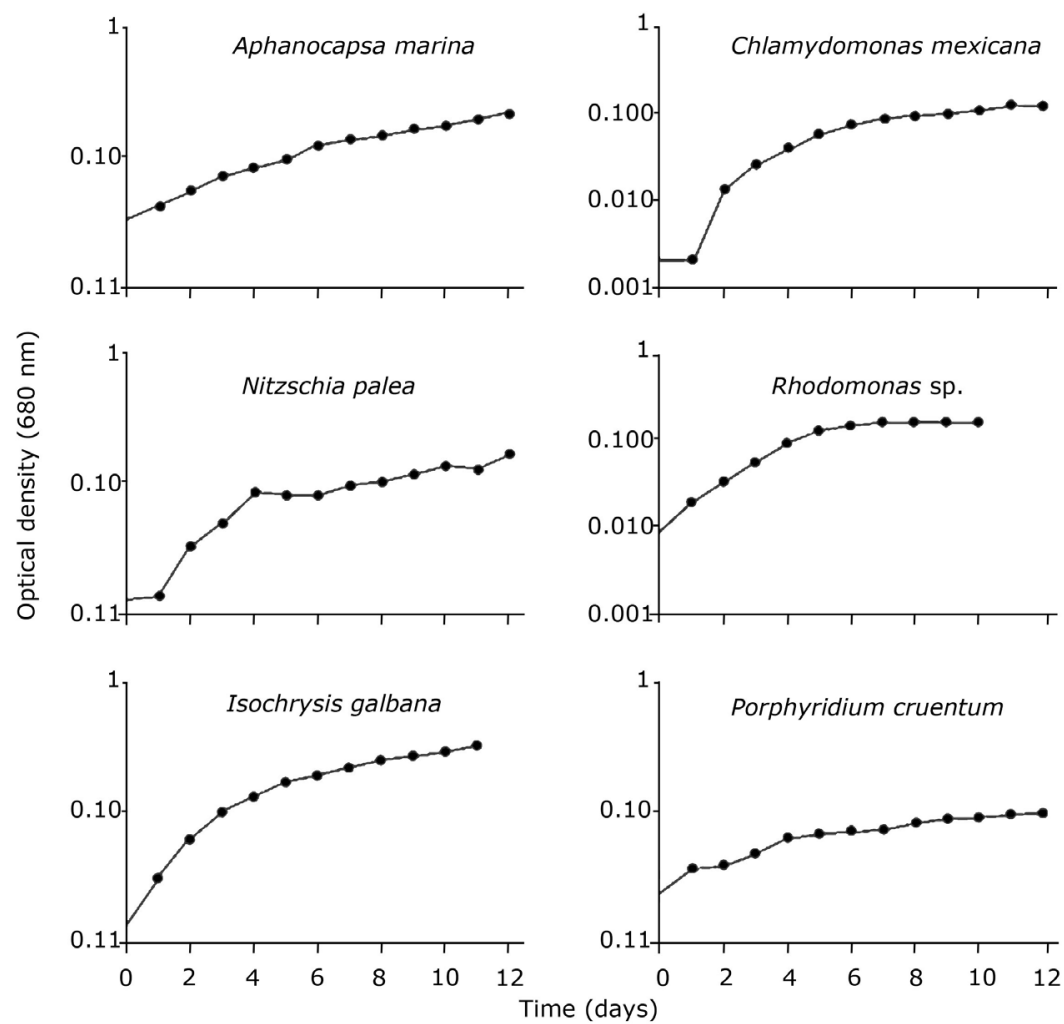

Figure 1. Growth curves for six microalgae strains used in this study / Curvas de crecimiento de seis cepas de microalgas utilizadas en este estudio 
were observed in biomass production and the extraction yield among microalgal strains (Table 2). The highest biomass production was for $A$. marina $\left(224.4 \mathrm{mg} \mathrm{l}^{-1}\right)$ while the lowest production was for $P$. cruentum $\left(60.7 \mathrm{mg} \mathrm{l}^{-1}\right)$. Likewise, the highest extraction yield was for I. galbana (7.7\%) while the lowest yield was for A. marina (1.0\%) and C. mexicana $(1 \%)$.

Significant differences were found $(P<0.05)$ on the percentage of inhibition of $M$. tuberculosis due DMSO concentrations (Fig. 2). DMSO at $0.5 \%$ did not affect the growth of $M$. tuberculosis, meanwhile, the concentrations of $1 \%$ of DMSO showed the lower effect on its growth. The concentrations of $2 \%$ of DMSO inhibited the growth of $M$. tuberculosis at values nearly $50 \%$, while the concentration of $5 \%$ of DMSO completely inhibited the growth of $M$. tuberculosis (Fig. 2).

\section{ANTIMYCOBACTERIAL ACTIVITY EVALUATION}

All of the hexane crude extracts of the six microalgae strains exhibited considerable antimycobacterial effect. The extracts of P. cruentum, C. mexicana and I. galbana inhibited mycobacterial growth with values of $99.4,98.4$ and $98.3 \%$ respectively to the same extent as isoniazid (99.4\%) (Fig. 3). Meanwhile, the extracts of $A$. marina
Table 2. Biomass harvest day, dry weight values, and extraction yield values for the different microalgae strains used / Día de cosecha de la biomasa, y valores de peso seco y de rendimiento de extracción para las diferentes microalgas utilizadas

\begin{tabular}{lccc}
\hline \multicolumn{1}{c}{ Microalgae strain } & $\begin{array}{c}\text { Harvest date } \\
(\text { day })\end{array}$ & $\begin{array}{c}\text { Dry weight } \\
\left(\mathrm{mg} \mathrm{l}^{-1}\right)\end{array}$ & $\begin{array}{c}\text { Extraction yield } \\
(\%)\end{array}$ \\
\hline $\begin{array}{l}\text { Cyanophyta } \\
\text { Aphanocapsa marina }\end{array}$ & 12 & 224.4 & 1.0 \\
$\begin{array}{l}\text { Chlorophyta } \\
\quad \text { Chlamydomonas mexicana }\end{array}$ & 12 & 103.5 & 1.0 \\
$\begin{array}{l}\text { Bacillariophyta } \\
\quad \text { Nitzschia palea }\end{array}$ & 12 & 143.8 & 2.2 \\
$\begin{array}{l}\text { Criptophyta } \\
\quad \text { Rhodomonas sp. }\end{array}$ & 11 & 119.2 & 4.2 \\
$\begin{array}{l}\text { Haptophyta } \\
\quad \text { ssochrysis galbana } \\
\text { Rhodophyta } \\
\quad \text { Porphyridium cruentum }\end{array}$ & 11 & 91.3 & 7.7 \\
\hline
\end{tabular}

(81.6\%), Rhodomonas sp. (89.3\%), and N. palea (95.4\%) showed about 80 to $90 \%$ of growth inhibition (Fig. 3). The lowest MIC was $50 \mu \mathrm{g} \mathrm{ml}^{-1}$, observed for the hexane crude extract of I. galbana (Fig. 4). For the remaining extracts, the MIC was the initial concentration that was used in the antimycobacterial assays: $100 \mu \mathrm{g} \mathrm{ml}^{-1}$. While, the MIC of isoniazid was $0.06 \mu \mathrm{g} \mathrm{ml}^{-1}$ (Fig. 4).

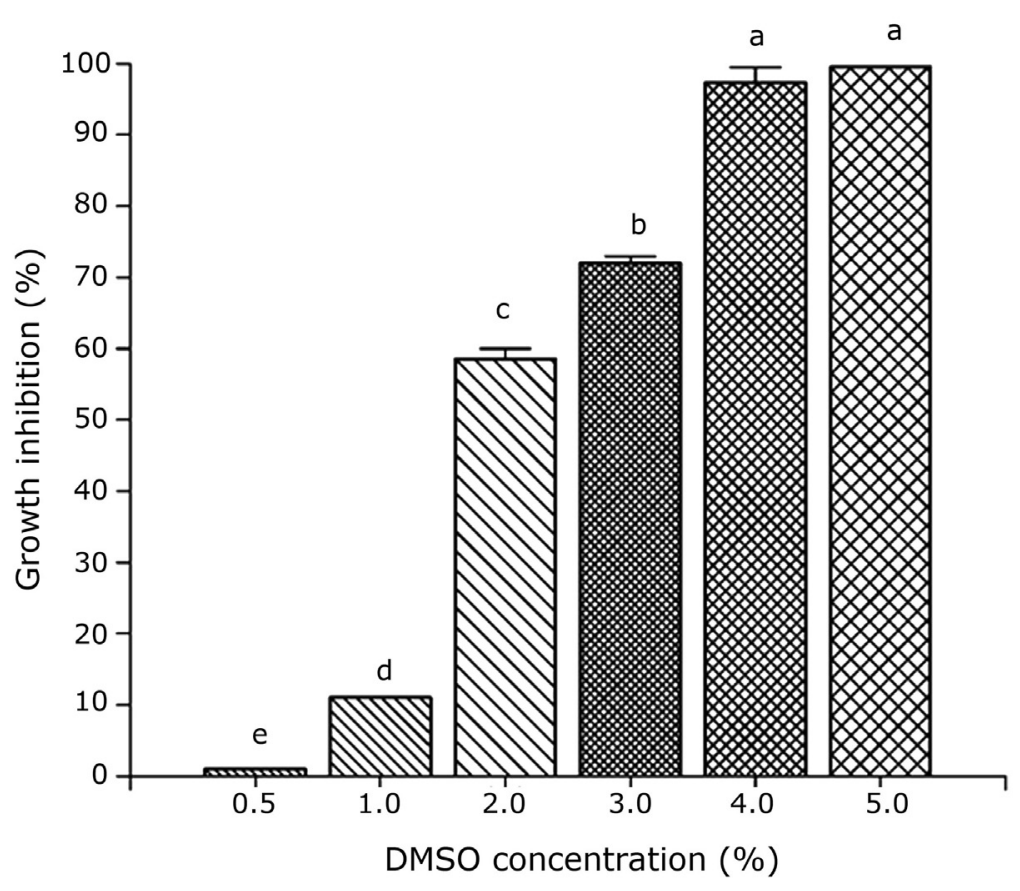

Figure 2. Mean values and standard deviations of growth inhibition of Mycobacterium tuberculosis by effect of differents concentrations of dimethyl sulfoxide (DMSO). Bars with different lowercase letters are significantly different (Kruskal-Wallis one-way ANOVA and Fisher's LSD post hoc test; $F=123,6, P<0,0001$, a $>b>c>d>e$; mean values $\pm S D ; n=3$ ) / Valores promedio y desviación estándar del porcentaje de inhibición del crecimiento de Mycobacterium tuberculosis por efecto de diferentes concentraciones de dimetil sulfóxido (DMSO). Las barras con letras minúsculas distintas son significativamente diferentes (ANOVA de una vía por KruskalWallis y prueba post hoc de LSD de Fisher; $F=126,6, P<0,0001$, a $>b>c>d>e$; los valores son el promedio \pm desviación estándar; $n=3$ ) 


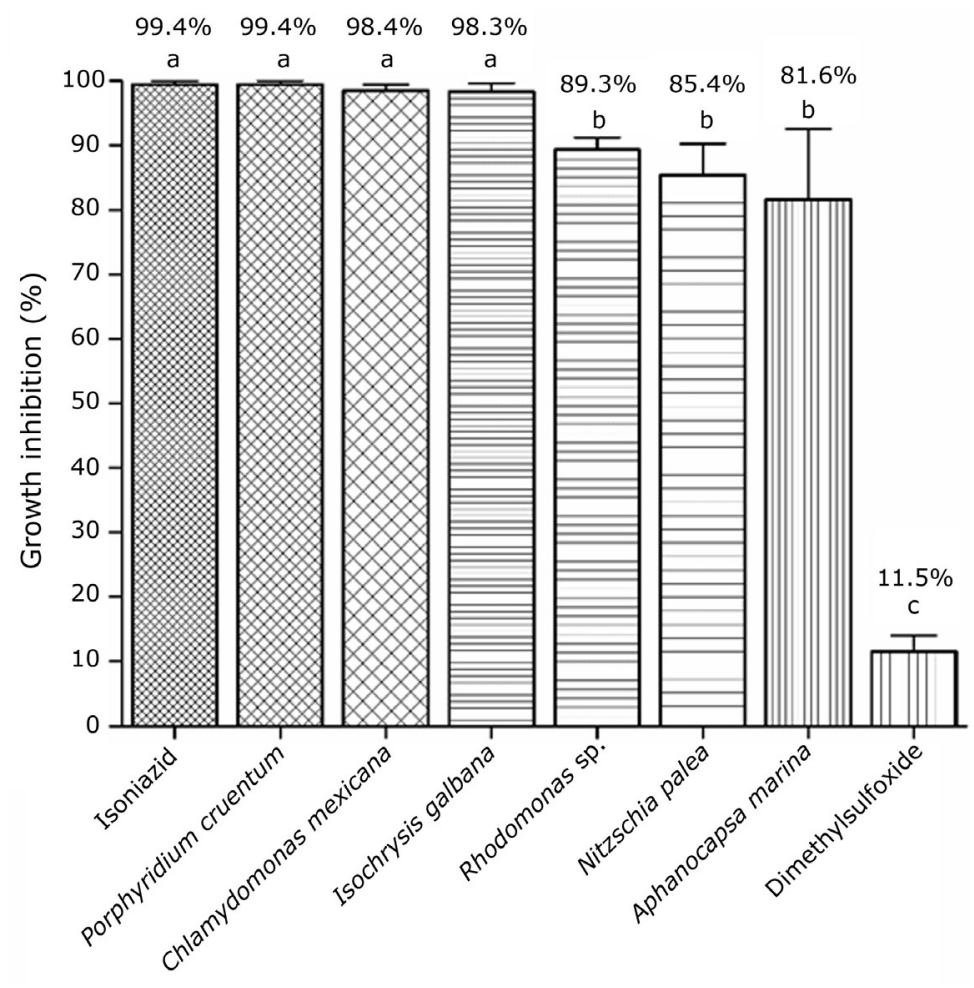

Figure 3. Percentage of growth inhibition by the crude extracts and control compounds against $1.5 \times 10^{7} \mathrm{CFU}$ $\mathrm{ml}^{-1}$ Mycobacterium tuberculosis H37Rv. Bars with different lowercase letters are significantly different (one-way ANOVA and Fisher's LSD post hoc test; $F=$ 126.3, $P<0.0001$, a $>b>c$; mean values $\pm S D ; n=3$ ) / Porcentaje de inhibición de extractos crudos y control en contra $1.5 \times 10^{7} \mathrm{CFU} \mathrm{ml}{ }^{-1}$ de Mycobacterium tuberculosis H37Rv. Las barras con letras minúsculas distintas son significativamente diferentes (ANOVA de una vía y prueba post hoc de LSD de Fisher; $F=126,3, P<0,0001$, $a>b>c$; promedio \pm desviación estándar; $n=3$ )

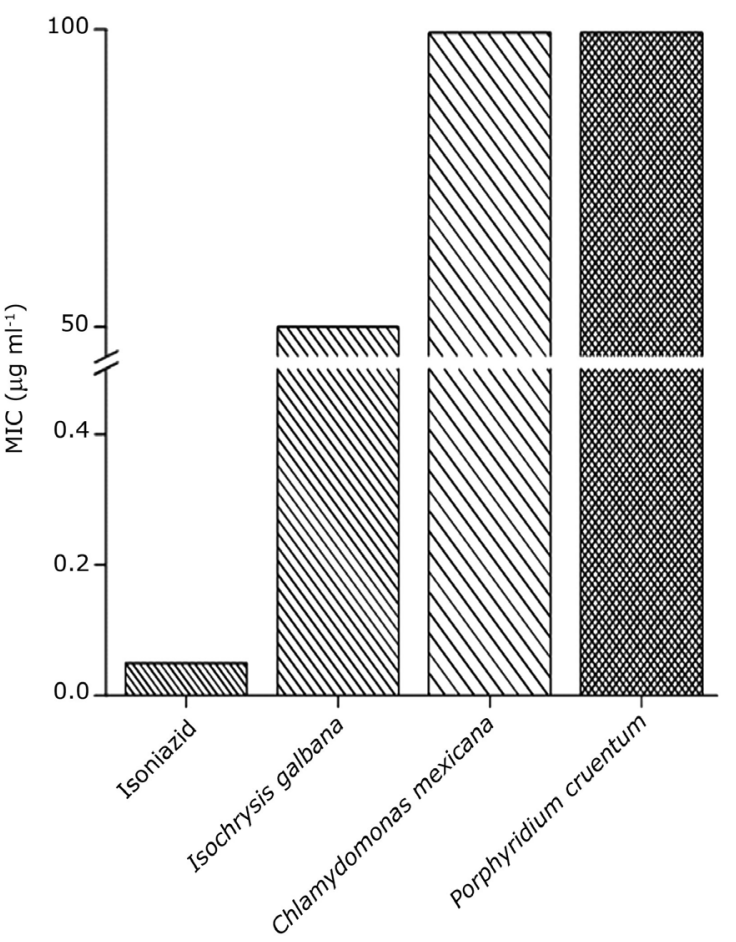

Figure 4. Minimum inhibitory concentration (MIC) values for the antituberculosis drug isoniazid and the crude extracts that showed a percentage of inhibition of growth equal to this drug / Valores de la concentración mínima inhibitoria (CMI) para el fármaco antituberculoso isoniazida y para los extractos crudos que tuvieron un porcentaje de inhibición del crecimiento igual a éste fármaco

\section{Discussion}

The differences in growth pattern and biomass production could be due to the adaptability of each strain to the culture conditions and the type of nutrients that are available in the culture medium, as has been reported for various classes of microalgae (Andersen 2005). The microalgal cultures were harvested in the stationary growth phase, in as much as is known that in microalgae the secondary metabolites which commonly possess bioactivity are synthesized during this stage (Namikoshi \& Rinehart 1996). When microalgae encounter unfavorable conditions, they tend to favor the adaptation and not the cell division. This adaptation elicits the production of secondary metabolites that confer an advantage during competition for the resources in the environment (Borowitzka 1995).

Methanol, ethanol, dichloromethane, chloroform and hexane are the most commonly used solvents for the extraction of bioactive metabolites from microalgae (Østensvik et al. 1998, Kreitlow et al. 1999, SánchezSaavedra et al. 2010). However, most of these studies do not report extraction yields (i.e., the weight of the mass obtained by evaporating the solvents). In this work the extraction percentages were calculated, in as much as the extraction yield can be good selection criteria among a group of extracts. It is known that the extraction yield depends 
on several factors such as the water content in the sample, the cellular physiology (e.g., whether they are coccoid or filamentous cells, cells with or without cell walls, and the polarity of the metabolites of interest) (Fastner et al. 1998).

The antimycobacterial activity of the hexane extracts of C. mexicana and I. galbana is consistent with other studies that have reported the antimycobacterial effects of crude extracts from Haptohyte and Chlorophyte microalgae (Prakash et al. 2010). On the other hand, to the best of our knowledge there are not reports about the antimycobacterial activity by microalgae belonging to phyla Rhodophyta, Cryptophyta or Bacillariophyta. Nonetheless, in this work, the hexane crude extracts from microalgae in these phyla considerably inhibited mycobacterial growth. Also, the antibacterial effects of extracts from Rhodophyta, Cryptophyta, and Bacillariophyta microalgae against various pathogenic bacteria, such as Staphylococcus aureus, Listonella anguillarum, Vibrio alginolyticus, and Bacillus subtilis, have been examined extensively (Kellam \& Walker 1989, Naviner et al. 1999). Conversely, Cyanophyta is the phylum with the greatest number of reports in literature about the antimycobacterial activity by microalgae (Rao et al. 2007, Chlipala et al. 2009, Broniatowska et al. 2011). Some studies that have identified the cyanobacterial compounds responsible for the antimycobacterial activity have found that they are compounds such as terpenes, peptides, alkaloids, aromatic compounds, cyclic peptides, cyclophane, extracellular pigments, phenols, polyketides, polyphenol ethers, terpenoids and anthraquinones (Mo et al. 2009, Sturdy et al. 2010, Swain et al. 2017).

Many authors consider that a crude extract that presents antimycobacterial activity with an MIC $\leq 100 \mu \mathrm{g} \mathrm{ml}^{-1}$, has the potential for the search of antituberculosis compounds (Molina-Salinas et al. 2006, Chlipala et al. 2009, Mayer et al. 2017). Based on this criterion, the extracts from $I$. galbana, C. mexicana, and P. cruentum are potential sources of antimycobacterial compounds. Notwithstanding, one must be cautious when the MIC value of a crude extract is used as the criterion in evaluating extracts. That an extract has a lower MIC compared with another extract does not necessarily mean that the active principle in the first extract is more potent than that of the second, because it is possible that the active compound in the first extract is found in a greater quantity than in the second extract. Thus, the activity of the active principle in the second extract can be underestimated (Pauli et al. 2005).
The antimycobacterial activity of hexane crude extracts from the six microalgae strains, probably was due to the presence of lipid-nature compounds such as saturated and unsaturated fatty acids, sterols and, terpenes. This is plausible because there are many studies that have reported the antimycobacterial activity of fatty acids and terpenes (Newton et al. 2000, Copp 2003), and it is well established that microalgae produce these types of compounds $(\mathrm{Hu}$ et al. 2008, Pattanaik \& Lindber 2015, Martínez-Francés \& Escudero-Oñate 2018). One approach to mitigating drug resistance in pathogenic bacteria is the use of new compounds that are unrelated to existing antibiotics (Eom et al. 2012). Marine organisms are a tremendous source of novel compounds to combat $\mathrm{Mtb}$ drug resistance, because they produce molecules with unique structural features compared with their terrestrial analogous (Larsen et al. 2005). To this end, many researcher groups worldwide have performed screenings of microalgae to discover novel antimycobacterial molecules and develop them into new antituberculosis drugs (Garcia et al. 2012, Mayer et al. 2017).

In conclusion, this study is the first -to the best of our knowledge- to report the antimycobacterial activity of more than two phyla of microalgae. We will analyze the hexane extracts of $P$. cruentum, C. mexicana, and I. galbana by bioassay-guided fractionation in order to isolate and characterize their antimycobacterial compounds. Lastly, our results are an incentive to continue the search for microalgal molecules with the potential to develop new antituberculosis drugs.

\section{ACKNOWLeDgments}

This work was funded by Consejo Nacional de Ciencia y Tecnología (CONACyT) Grant Project: SEP-CONACyT 2009-01-130074 and Centro de Investigación Científica y de Educación Superior de Ensenada (CICESE) Grant Projects: 623108 and 623801 . The first author is grateful to CONACyT and CICESE for the support granted through a scholarship for graduate studies. Thanks to Ceres MolinaCárdenas and Johanna Bernáldez-Sarabia for technical assistance. English language was edited by Blue-Pencil Science. 


\section{LITERATURE CITED}

Andersen RA. 2005. Algal culturing techniques, 578 pp. Elsevier Academic Press, New York.

Beutler JA. 2009. Natural products as a foundation for drug discovery. Current Protocols in Pharmacology 46: 1-30.

Borowitzka MA. 1995. Microalgae as sources of pharmaceuticals and other biologically active compounds. Journal Applied Phycology 7: 3-15.

Broniatowska B, A Allmendinger, M Kaiser, D MontamatSicotte, S Hingley-Wilson, A Lalvani., M Guiry, G Blunden \& D Tasdemir. 2011. Antiprotozoal, antitubercular and cytotoxic potential of cyanobacterial (blue-green algal) extracts from Ireland. Natural Products Communications 6: 689-694.

Chlipala G, S Mo, E Carcache-de Blanco, A Ito, S Bazarek \& J Orjala. 2009. Investigation of antimicrobial and protease-inhibitory activity from cultured cyanobacteria. Pharmaceutical Biology 47: 53-60.

Collins LS \& SG Franzblau. 1997. Microplate Alamar Blue assay versus BACTEC 460 system for high throughput screening of compounds against Mycobacterium tuberculosis and Mycobacterium avium. Antimicrobial Agents and Chemotherapy 41: 1004-1009.

Copp BR. 2003. Antimycobacterial natural products. Natural Products Reports 20: 535-557.

Dawson RM. 1998. The ecology of microcystins: Review. Toxicon 7: 953-962.

Eom SH, YM Kim \& SK Kim. 2012. Antimicrobial effect of phlorotannins from marine brown algae. Food Chemistry and Toxicology 50: 3251-3255.

Fallarero A, L Hanski \& P Vuolera. 2015. How to translate a bioassay into a screening assay for natural products: general considerations and implementation of antimicrobial screens. Planta Medical 80: 1182-1199.

Fastner J, I Flieger \& U Neumann. 1998. Optimized extraction of microcystins from field samples: a comparison of different solvents and procedures. Water Research 32: 3177-3181.

Fernandes-Ramos D, A Matthiensen, W Colvara, AP Souza de Votto, G Santos-Trindade, PE Almeida-Da Silva \& J Sarkis-Yunes. 2015. Antimycobacterial and cytotoxicity activity of microcystins. Journal of Venomous Animals and Toxins including Tropical Diseases 21(9): 1-7.

Fierro-Reséndiz S. 2006. Informe de actividades de aislamiento y caracterización de cepas aisladas de granjas camaronícolas de Mexicali, Baja California. Reporte Técnico de Proyecto CONACyT 45844, Centro de Investigación Científica y de Educación Superior de Ensenada (CICESE), Ensenada, $103 \mathrm{pp}$.

Galvao J, B Davis, M Tilley, E Normando, MR Duchen \& MF Cordeiro. 2014. Unexpected low-dose toxicity of the universal solvent DMSO. The FASEB Journal 28(3): 1317-1330.

Garcia A, V Bocanegra-García, JP Palma-Nicolás \& G Rivera. 2012. Recent advances in antitubercular natural products. European Journal of Medicinal Chemistry 49: $1-23$.
González-Davis O, E Ponce-Rivas, MPSánchez-Saavedra, ME Muñoz-Márquez \& WH Gerwick. 2012. Bioprospection of microalgae and cyanobacteria as biocontrol agents against Vibrio campbellii and their use in white shrimp Litopenaeus vannamei culture. Journal of the World Aquaculture Society 43: 387-399.

Guillard RLL \& JH Ryther. 1962. Studies on marine planktonic diatoms. I. Cyclotella nana Hustedt and Detonula confervacea (Cleve) Gran. Canadian Journal of Microbiology 8: 229-239.

Hoagland DT, J Liu, RB Lee \& RE Lee. 2016. New agents for the treatment of drug-resistant Mycobacterium tuberculosis. Advanced Drug Delivery Reviews 102: 55-72.

Hu Q, M Sommerfeld, E Jarvis, M Ghirardi, M Posewitz, M Seibert \& A Darzins. 2008. Microalgal triacylglycerol's as feedstock's for biofuel production: perspectives and advances. The Plant Journal 54: 621-639.

INDRE. 2014. Lineamientos para la vigilancia epidemiológica de la tuberculosis por laboratorio. Instituto de Diagnóstico y Referencia Epidemiológicos 'Dr. Manuel Martínez Báez' Dirección General de Epidemiología. Secretaría de Salud, México. <https://www.gob.mx/cms/uploads/attachment/ file/66202/Lineamientos_para_vigilancia_por_laboratorio_ de_tuberculosis.pdf $>$

Jiménez-Valera S \& MP Sánchez-Saavedra. 2016. Growth and biochemical composition of microalgae species isolated from the Baja California Peninsula, México. Latin American Journal of Aquaculture Research 44: 689-702.

Kellam SJ \& JM Walker. 1989. Antibacterial activity from marine microalgae in laboratory culture. British Phycology Journal 24: 191-194.

Kreitlow S, S Mundt \& U Lindequist. 1999. Cyanobacteria -a potential source of new biologically active substances. Journal of Biotechnology 70: 61-63.

Larsen TO, J Smedsgaard, KF Nielsen, ME Hansen \& JC Frisvad. 2005. Phenotypic taxonomy and metabolite profiling in microbial drug discovery. Natural Products Reports 22: 672-695.

Lauritano Ch, J Martin, M de la Cruz, F Reyes, G Romano \& A Ianora. 2018. First identification of marine diatoms with anti-tuberculosis activity. Scientific Reports 8: 2284. <doi:10.1038/s41598-018-20611-x>

Luo S, H Kang, A Krunik, G Chilpala, G Cai, W Chen, S Franzblau, S Swanson \& J Orjala. 2014. Carbamidocyclophanes $\mathrm{F}$ and $\mathrm{G}$ with anti-mycobacterium tuberculosis activity from the cultured freshwater cyanobacterium Nostoc sp. Tetrahedron Letters 55: 686-689.

MacFaddin JF. 1985. Media for isolation, cultivation, identification and maintenance of medical bacteri, $928 \mathrm{pp}$. Williams and Wilkins, Baltimore.

Martínez-Francés E \& C Escudero-Oñate. 2018. Cyanobacteria and microalgae in the production of valuable bioactive compounds. In: Jacob-Lopes E, L Queiroz-Zepta \& MI Queiroz (eds). Microalgal biotechnology 6: 104-128. IntechOpen, London <doi: 10.5772/intechopen.74043> 
Mayer A, AD Rodríguez, O Taglialatela-Scafati \& N Fusetani. 2017. Marine pharmacology in 2012-2013: Marine compounds with antibacterial, antidiabetic, antifungal, antiinflammatory, antiprotozoal, antituberculosis, and antiviral activities; affecting the immune and nervous systems, and other miscellaneous mechanisms of action. Marine Drugs 15(9): 2510-2573. <doi: 10.3390/md11072510>

Migliori GB, R Loddenkemper, F Blasi \& MC Raviglione. 2007. 125 years after Robert Koch's discovery of the tubercle bacillus: The new XDR-TB threat. Is "science" enough to tackle the epidemic? European Respiratory Journal 29: 423-427.

Mo S, A Krunic, SD Pegan, SG Franzblau \& J Orjala. 2009. An antimicrobial guanidine-bearing sesterterpene from the cultured cyanobacterium Scytonema sp. Journal of Natural Products 72: 2043-2045.

Molina-Cárdenas CA \& MP Sánchez-Saavedra. 2017. Inhibitory effect of benthic diatom species on three aquaculture pathogenic Vibrios. Algal Research 27: 131-139.

Molina-Salinas GM, MC Ramos-Guerra, J VargasVillarreal, BD Mata-Cárdenas, P Becerril-Montes \& S Said-Fernández. 2006. Bactericidal activity of organic extracts from Flourensia cernua DC against strains of Mycobacterium tuberculosis. Archives of Medical Research 37: 45-49.

Namikoshi M \& K Rinehart. 1996. Bioactive compounds produced by cyanobacteria. Journal of Indian Microbiology 17: $373-384$

Naviner M, JP Bergé, P Durand \& H Le Bris. 1999. Antibacterial activity of the marine diatom Skeletonema costatum against aquacultural pathogens. Aquaculture 174: 15-24.

Newton SM, C Lau \& CW Wright. 2000. A review of antimycobacterial natural products. Phytotherapy Research 14: 303-322.

Østensvik Ø, OM Skulberg, B Underdal \& V Hormazabal. 1998. Antibacterial properties of extracts from selected planktonic freshwater cyanobacteria - A comparative study of bacterial bioassays. Journal of Applied Microbiology 84: 1117-1124.

Palomino JC, A Martin \& F Portaels. 2007. Rapid drug resistance detection in Mycobacterium tuberculosis: A review of colourimetric methods. Clinical Microbiology and Infection 13: 754-762.
Pattanaik B \& P Lindberg. 2015. Terpenoids and their biosynthesis in cyanobacteria. Life 5: 269-293.

Pauli GF, RJ Case, T Inui, Y Wang, S Cho, NH Fischer \& SG Franzblau. 2005. New perspectives on natural products in TB drug research. Life Science 78: 485-494.

Powers JH. 2004. Antimicrobial drug development the past, the present, and the future. Clinical Microbiology and Infection 10: 23-31.

Prakash S, V Huxley \& J Aldous. 2010. Isolation and identification of MDR-Mycobacterium tuberculosis and screening of partially characterized antimycobacterial compounds from chosen marine microalgae. Asian Pacific Journal of Tropical Medicine 8: 656-661.

Pulz O \& W Gross. 2004. Valuable products from biotechnology of microalgae. Applied Microbiology and Biotechnology 65: 635-648

Rao M, S Malhatra, T Fatma \& A Ratta. 2007. Antimycobacterial activity from cyanobacterial extracts and phytochemical screening of methanol extract of Hapalosiphon. Pharmaceutical Biology 45: 88-93.

Sánchez-Saavedra MP, A Licea-Navarro \& J BernáldezSarabia. 2010. Evaluation of the antibacterial activity of different species of phytoplankton. Revista de Biología Marina y Oceanografía 45: 531-536.

Sotgiu G \& GB Migliori. 2015. Facing multi-drug resistant tuberculosis. Pulmonary Pharmacology and Therapeutics 32: $144-148$

Sturdy M, A Krunic, S Cho, S Franzblau \& J Orjala. 2010. Eucapsitrione, an anti- Mycobacterium tuberculosis anthraquinone derivative from the cultured freshwater cyanobacterium Eucapsis sp. Journal of Natural Products 73: 1441-1443.

Swain S, SK Paidesetty \& RA Padhy. 2017. Antibacterial, antifungal and antimycobacterial compounds from cyanobacteria. Biomedicine \& Pharmacology 90: 760-776.

Whitton BA \& M Potts. 2000. The ecology of cyanobacteria: Their diversity in time and space, $669 \mathrm{pp}$. Springer, Amsterdam.

WHO. 2016. Global tuberculosis report 2016. World Health Organization, Geneva. <http://apps.who.int/medicinedocs/ documents/s23098en/s23098en.pdf>

Zar JH. 2010. Biostatistical analysis, 944 pp. Prentice-Hall/ Pearson, Upper Saddle River. 